\title{
CORRELATION OF MECHANICAL PROPERTIES AND RESISTANCE TO PERFORATION OF ARMOUR ELEMENTS MADE OF NANOSTRUCTURED BAINITIC STEEL
}

\author{
OPRACOWANIE KORELACJI WŁAŚCIWOŚCI MECHANICZNYCH \\ ORAZ ODPORNOŚCI NA PRZEBICIE ELEMENTÓW OPANCERZENIA \\ ZE STALI NANOSTRUKTURALNEJ BAINITYCZNEJ
}

\begin{abstract}
The aim of the paper is to determine the correlation between mechanical properties determined in quasi-static tensile tests and dynamic compression tests, and resistance to perforation and cracking in firing tests of nanostructured bainitic steel sheets. The relationship between mechanical characteristics and ballistic resistance makes it possible to specify and optimise the production parameters of steel elements for armour and shields providing ballistic protection. As a result of the tests, the level of mechanical parameters and the type of microstructure, as well as the minimum thickness of the nanostructured bainitic steel sheet, ensuring compliance with the requirements of level 2 ballistic protection according to Stanag 4569, were determined.
\end{abstract}

Keywords: nanostructured bainitic steel, dynamic deformation, mechanical properties, microstructure, ballistic resistance

\section{INTRODUCTION}

One of the main directions of development of technology for the production of high-strength structural steels is the pursuit of the highest possible strength, while ensuring sufficient plasticity, ductility and/or resistance to cracking for specific applications. A new approach to the production of nanostructures in steels proposed by Bhadeshia about two decades ago, consisting in controlling the course of isothermal phase transformation in the temperature range below $300^{\circ} \mathrm{C}$, led to the development of the basis for the production of nanostructured steels with a structure of carbide-free lower bainite and retained austenite in the amount of $15-35 \%$ of volume. The results of examination on nanostructured bainitic steel grades carried out at IMŻ thus far show that it is possible to achieve the properties of products (sheets and bars) at the following level: ultimate tensile strength of 1.8-2.2 GPa, yield strength of 1.2-1.6 GPa, total elongation of $12-20 \%$ in a static tensile test and hardness of

Corresponding Author: jaroslaw.marcisz@imz.pl
Przedmiotem artykutu jest ustalanie korelacji pomiędzy wtaściwościami mechanicznymi wyznaczonymi w quasistatycznych testach rozciagania $i$ dynamicznych testach ściskania a odpornościa na przebicie i na pękanie w testach ostrzatem blach ze stali nanostrukturalnej bainitycznej.Zależności pomiędzy charakterystykami mechanicznymi a weskaźnikami odporności balistycznej umożliwiaja uściślenie $i$ zoptymalizowanie parametrów wytwarzania elementów stalowych do zastosowań na pancerze i ostony przed ostrzatem. W wyniku badań ustalono poziom parametrów mechanicznych i rodzaj mikrostruktury oraz minimalna grubość blachy ze stali nanostrukturalnej bainitycznej, zapewniajace spetnienie wymagań poziomu ochrony balistycznej 2 wg Stanag 4569.

Stowa kluczore: stal nanostrukturalna bainityczna, odkształcenie dynamiczne, wtaściwości mechaniczne, mikrostruktura, odporność balistyczna
550-650 HV10. The problem requiring further research in order to commercialise the applications of products made of nanostructured bainitic steel is the development of grade variants in terms of the content of individual elements and production parameters adapted to these compositions, ensuring the best performance properties for specific applications.

Optimisation of production process for nanostructured bainitic steel products for various applications - including armour components, especially in the scope of chemical composition and final heat treatment parameters, is still the subject of research in many scientific centres (e.g. [1-7]). Understanding the material properties determined in static and dynamic laboratory tests that determine resistance to high-energy impact (e.g. in firing tests) requires the development of an appropriately extensive database. Such a database is necessary to identify material parameters (characteristics) relevant for applications where extreme dynamic impacts occur. The paper contains the results of the study being a continuation of research $[8,9]$ regarding the development of broadly defined operational characteristics in order to expand the range of products made of nanostructured bainitic steel. 


\section{MATERIAL, SCOPE AND METHODOLOGY}

The examined material consisted of sections of nanostructured bainitic steel (NBA) with the following composition Fe-0.58\%C-1.9\%Mn-1.8\%Si-1.3\%Cr-0.75\%Mo (weight \%). The calculated $M s$ temperature of the material was approx. $200^{\circ} \mathrm{C}$. The samples were subjected to heat treatment including the following stages: austenitising at $950^{\circ} \mathrm{C}$ for 30 minutes, air cooling and direct annealing at isothermal transformation temperature. Two transformation temperatures were used: $210^{\circ} \mathrm{C}$ and $225^{\circ} \mathrm{C}$, which were selected on the basis of tests carried out so far. Isothermal annealing temperatures 10 and $25^{\circ} \mathrm{C}$ higher than the $M s$ temperature of the tested steel were selected, which had a significant impact on the transformation kinetics and thus on the type of microstructure and properties obtained. An isothermal annealing time from 54 to 144 hours was used for each of these temperatures.

The scope of tests established in order to select the optimal heat treatment parameters of nanobainitic steel sheets for the chemical composition of the material being tested includes microstructure characteristics, measurement of retained austenite content and measurement of mechanical properties in quasi-static tensile tests and dynamic compression tests. The tests using the Hopkinson bar method were carried out at the Military University of Technology. For optimal variants, sheet samples were produced for firing tests and the tests were carried out at the Military Institute of Armoured and Automotive Technology (WITPiS). The structure was examined in the area were the projectiles impacted the sheet.

\section{RESULTS OF THE EXAMINATION OF MECHANICAL PROPERTIES AND MICROSTRUCTURE}

\subsection{MECHANICAL PROPERTIES IN A STATIC TENSILE TEST}

The results of the examination of mechanical properties in a static tensile test are shown in Table 1. For the transformation temperature of $210^{\circ} \mathrm{C}$, the yield strength (YS) values were obtained in a wide range from approx. $800 \mathrm{MPa}$ to $1400 \mathrm{MPa}$, while for the temperature of $225^{\circ} \mathrm{C}$, YS was from approx. 1200 to $1450 \mathrm{MPa}$. The highest ultimate tensile strength (UTS) was obtained at $210^{\circ} \mathrm{C}$ and was approx. $2250 \mathrm{MPa}$. Bold elements in Table 2 indicate the heat treatment variants for which a favourable set of parameters determined in a static tensile test, in particular strength and elongation, was obtained. The results of the analysis showed that for an annealing temperature of $210^{\circ} \mathrm{C}$, maximum UTS above $2100 \mathrm{MPa}$ can be obtained, and for a temperature of $225^{\circ} \mathrm{C}$ a yield strength, higher than $1400 \mathrm{MPa}$, can be obtained while maintaining good plasticity. Based on the results of the measurement of mechanical properties, for a given temperature, the range of isothermal annealing time was determined, as a result of which the required set of properties was obtained. At $210^{\circ} \mathrm{C}$ it is from 96 to 120 hours, and at $225^{\circ} \mathrm{C}$ from 72 to 96 hours. Within the above temperature and time range, further studies were carried out to optimise performance.
Table 1. Results of the measurement of mechanical properties in a static tensile test; determination of heat treatment of samples: NBA/isothermal transformation temperature in ${ }^{\circ} \mathrm{C} /$ annealing time in hours

Tabela 1. Wyniki pomiarów właściwości mechanicznych w statycznej próbie rozciągania; oznaczenie obróbki cieplnej próbek: NBA/temperatura przemiany izotermicznej $w^{\circ} \mathrm{C} / \mathrm{czas}$ wygrzewania $w$ godzinach

\begin{tabular}{|c|c|c|c|c|}
\hline $\begin{array}{l}\text { Variant designation } \\
\left(950^{\circ} \mathrm{C} / 30 \mathrm{~min}+\right. \\
\text { air cooling })\end{array}$ & $\begin{array}{c}\text { YS } \\
{[\mathbf{M P a}]}\end{array}$ & $\begin{array}{c}\text { UTS } \\
\text { [MPa] }\end{array}$ & $\begin{array}{c}\text { TE } \\
{[\%]}\end{array}$ & UTS/YS \\
\hline \multirow{2}{*}{$\mathrm{NBA} / 210 / 54$} & 848 & 2245 & 7.5 & 2.65 \\
\hline & 822 & 2253 & 11.5 & 2.74 \\
\hline \multirow{2}{*}{$\mathrm{NBA} / 210 / 72$} & 1125 & 2157 & 13.1 & 1.92 \\
\hline & 1129 & 2207 & 9.8 & 1.95 \\
\hline \multirow{2}{*}{$\mathrm{NBA} / 210 / 96$} & 1265 & 2143 & 10.2 & 1.69 \\
\hline & 1269 & 2152 & 13.1 & 1.70 \\
\hline \multirow{2}{*}{$\mathrm{NBA} / 210 / 120$} & 1305 & 2130 & 11.6 & 1.63 \\
\hline & 1302 & 2130 & 14.4 & 1.64 \\
\hline \multirow{2}{*}{$\mathrm{NBA} / 210 / 144$} & 1398 & 2087 & 10.7 & 1.49 \\
\hline & 1381 & 2081 & 14.0 & 1.51 \\
\hline $\mathrm{NBA} / 225 / 54$ & 1231 & 2046 & 11.5 & 1.66 \\
\hline \multirow{2}{*}{$\mathrm{NBA} / 225 / 72$} & 1378 & 2025 & 14.9 & 1.47 \\
\hline & 1418 & 2031 & 10.2 & 1.43 \\
\hline \multirow{2}{*}{$\mathrm{NBA} / 225 / 96$} & 1461 & 1991 & 10.4 & 1.36 \\
\hline & 1397 & 1992 & 14.7 & 1.43 \\
\hline \multirow{2}{*}{$\mathrm{NBA} / 225 / 120$} & 1430 & 1992 & 15.5 & 1.39 \\
\hline & 1352 & 1993 & 10.7 & 1.47 \\
\hline \multirow{2}{*}{$\mathrm{NBA} / 225 / 144$} & 1473 & 1986 & 13.1 & 1.35 \\
\hline & 1322 & 1984 & 14.2 & 1.50 \\
\hline
\end{tabular}

YS - yield strength, UTS - ultimate tensile strength, TE - total elongation

\subsection{RESULTS OF THE EXAMINATION OF MICROSTRUCTURE AND DETERMINATION OF VOLUME FRACTION OF RETAINED AUSTENITE}

Fig. 1 shows an example of the microstructure of the tested steel after isothermal heat treatment at $210^{\circ} \mathrm{C}$ and $225^{\circ} \mathrm{C}$. At the magnifications used in the light microscope and scanning electron microscope, lower lath bainite packets were observed, and single martensite laths were observed in the 210/120 sample. The microstructure images do not clearly indicate all retained blocky austenite, which is clearly illustrated using the EBSD method. The banding of the microstructure was observed in the form of bands with different susceptibility to etching, uniformly distributed over the thickness of the tested samples, with distances between adjacent bands from about 40 to $100 \mu \mathrm{m}$. The microstructure morphology of the tested variants is similar, except for sample 210/54, in which retained blocky austenite is visible, in particular in segregation bands.

The results of the measurement of the volume fraction of retained austenite using the X-ray method $\left(A r_{\mathrm{X}}\right.$ - total amount of blocky and lathy austenite) are presented in Table 2. Table 2 also presents the results of the measurement of the volume fraction of blocky austenite determined using the EBSD method for several heat treatment variants $\left(A r_{\mathrm{EBSD}}\right)$. For these variants, volume fraction of lathy austenite was determined as the difference $A r_{\mathrm{X}}-A r_{\mathrm{EBSD}}$. The blocky austenite measurement for the 225/96 specimen will be completed because of the segregation influenced the transformation kinetics of undercooled austenite to bainite. 

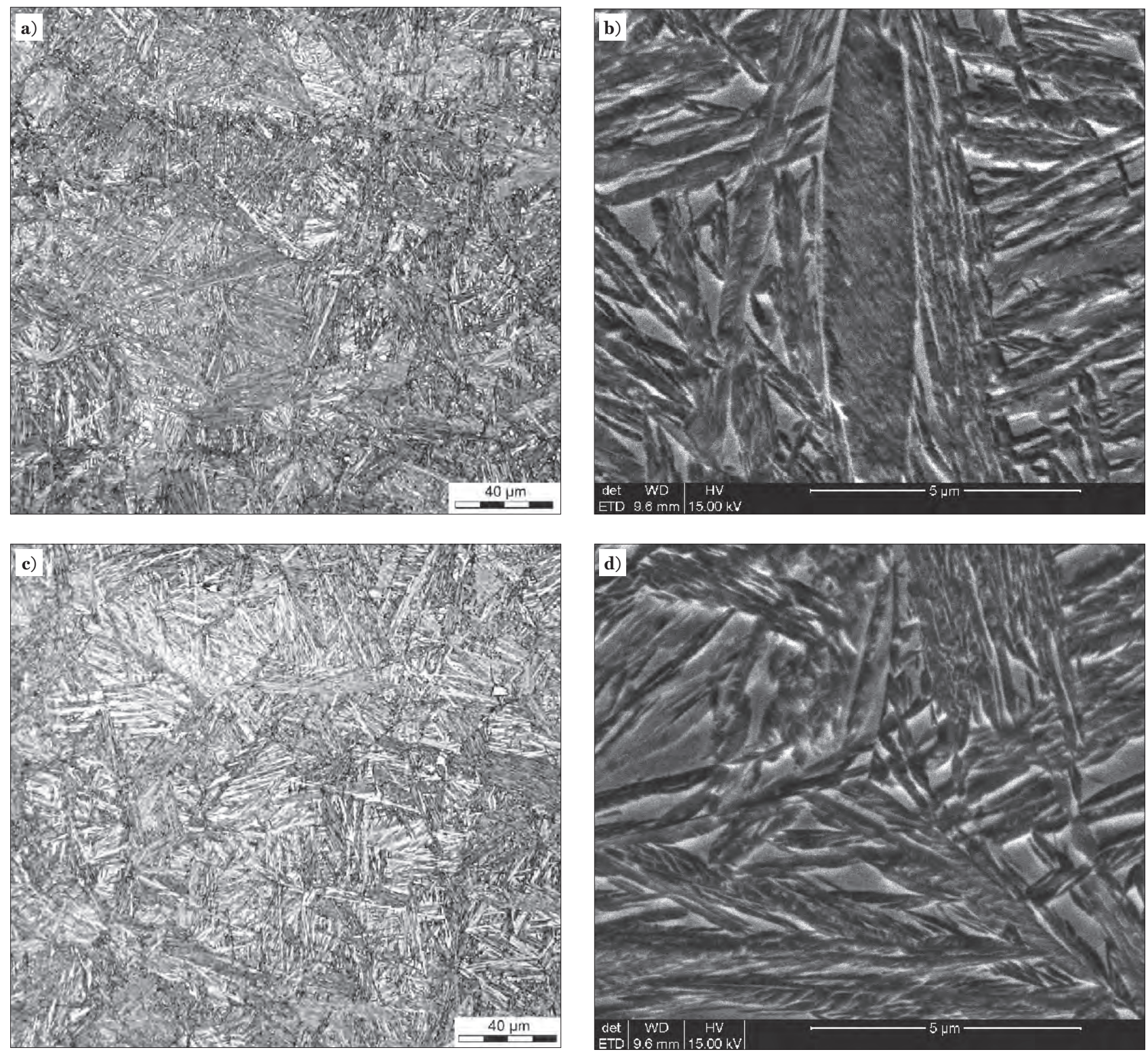

Fig. 1. Microstructure of nanostructured bainitic steel after isothermal annealing at $210^{\circ} \mathrm{C}$ for 120 hours $(\mathrm{a}, \mathrm{b})$ and at $225^{\circ} \mathrm{C}$ for $72 \mathrm{hours}(\mathrm{c}, \mathrm{d})$. a, c) light microscope, b, d) scanning electron microscope

Rys. 1. Mikrostruktura stali bainitycznej nanostrukturalnej po wygrzewaniu izotermicznym w temperaturze $210^{\circ} \mathrm{C}$ przez 120 godzin $($ a, b) i w temperaturze $225^{\circ} \mathrm{C}$ przez 72 godziny (c, d). a, c) mikroskop świetlny, b, d) skaningowy mikroskop elektronowy

Table 2. Results of retained austenite volume fraction measurement using the X-ray method. The table presents the contents of blocky retained austenite determined using the EBSD method for selected heat treatment variants

Tabela 2. Wyniki pomiarów ułamka objętości austenitu resztkowego metodą RTG. W tabeli podano zawartości austenitu resztkowego blokowego określonego z zastosowaniem metody EBDS dla wybranych wariantów obróbki cieplnej

\begin{tabular}{|c|c|}
\hline Heat treatment variant & Volume fraction of retained austenite, $\%$ \\
\hline $210 / 54$ & 23.3 \\
\hline $210 / 72$ & 22.6 \\
\hline $210 / 96$ & $26.7 / \mathbf{1 0 . 0}(\mathbf{E B S D})$ \\
\hline $210 / 120$ & $16.1 / \mathbf{1 3 . 0}(\mathbf{E B S D})$ \\
\hline $210 / 144$ & 18.8 \\
\hline $225 / 54$ & 26.8 \\
\hline $225 / 72$ & $26.8 / \mathbf{1 3 . 0}(\mathbf{E B S D})$ \\
\hline $225 / 96$ & $17.2 / \mathbf{1 7 . 0}(\mathbf{E B S D})$ \\
\hline $225 / 120$ & 25.2 \\
\hline $225 / 144$ & 18.3 \\
\hline
\end{tabular}

The morphology analysis and measurement of retained blocky austenite were carried out using the EBSD method for selected heat treatment variants. The results of the measurement and observations of the retained blocky austenite morphology are given in Fig. 2. Retained blocky austenite is uniformly distributed in the examined volume of the material, and the average intercept/width of grains/laths of this phase is in the range from tenths of microns to several microns. In assessing the volume fraction, a representative area and appropriate magnification should be selected. For nanostructured steel in the examined variants of isothermal heat treatment, the content of blocky retained austenite was $210 / 96-10 \%, 210 / 120-13 \%$ and $225 / 72-13 \%, 225 / 96-17 \%$. Determination of the volume fraction of total retained austenite, including the content of blocky austenite and austenite in the form of nano-laths, is important for understanding the effect of austenite on the performance properties of nanostructured bainitic steels. 

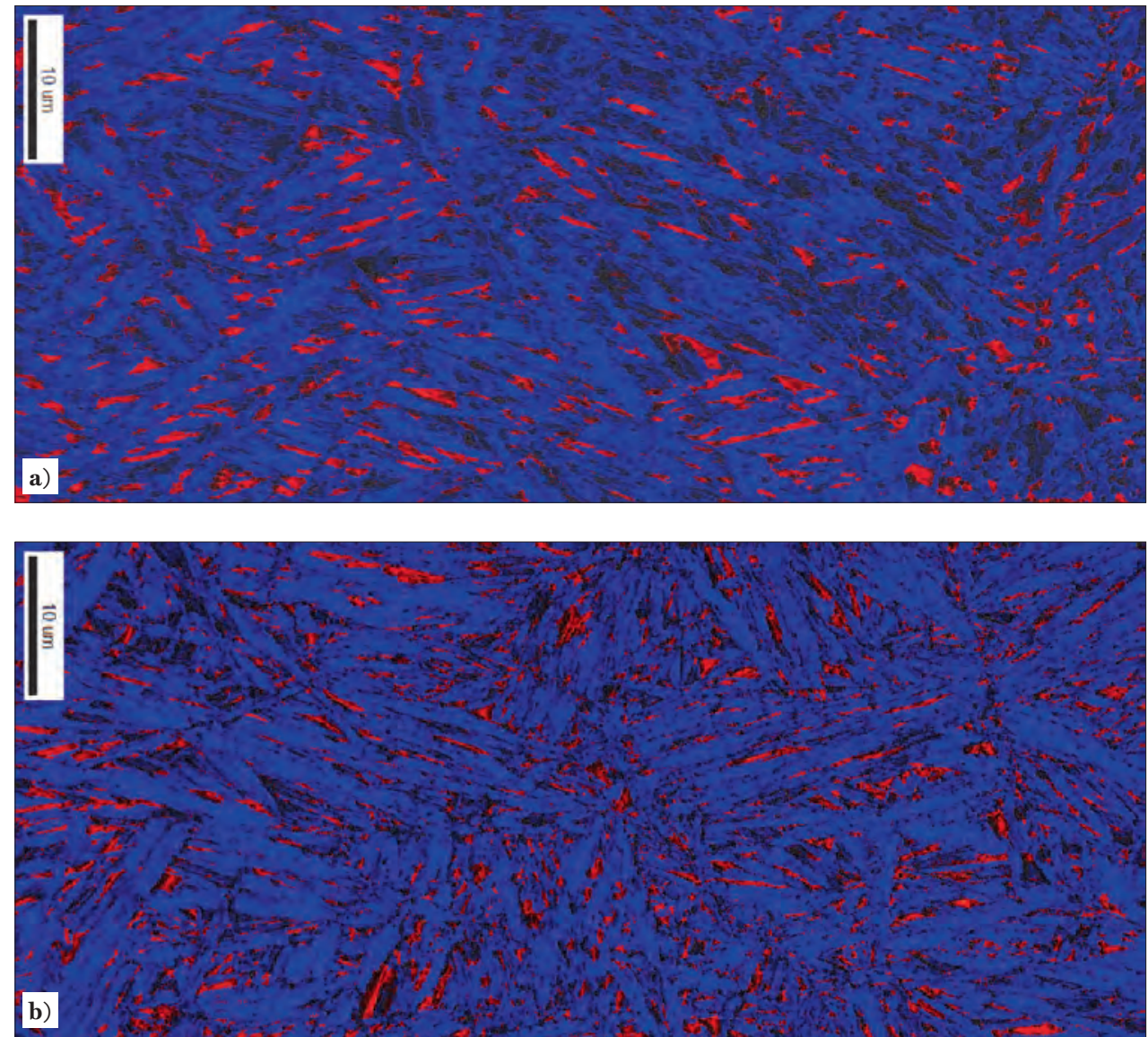

Fig. 2. Results of EBSD analysis. Nanostructured bainitic steel, variants 210/96 (a) and 225/72(b), (laths and grains of retained austenite are distinguished with red). Scanning electron microscope

Rys. 2. Wyniki analizy EBSD. Stal nanostrukturalna bainityczna, wariant 210/96 (a) i 225/72 (a) (kolorem czerwonym wyróżniono listwy i ziarna austenitu resztkowego). Skaningowy mikroskop elektronowy

\subsection{RESULTS OF THE EXAMINATION OF MULTIPLE DYNAMIC DEFORMATION OF NANOBAINITE}

Examination was carried out on nanostructured bainitic steel subjected to multiple dynamic deformation using a Hopkinson bar and a Gleeble simulator. Multiple deformation was performed using the Hopkinson method with uniaxial compression of samples with diameters of 4.0 and $5.0 \mathrm{~mm}$ and a height of $5.0 \mathrm{~mm}$. Using the Gleeble simulator, uniaxial double compression was carried out with a constant strain rate of $50 \mathrm{~s}^{-1}$. In these experiments, samples with a diameter and height of $5.0 \mathrm{~mm}$ were used, for which total strain values up to 0.50 were obtained. The time between the first and second compression was $30 \mathrm{~s}$ and ensured that the sample and anvils reached the ambient temperature before the second deformation.

As a result of dynamic compression experiments using the Hopkinson technique, stress-strain curves were determined in the range of strain rate of $300-1900 \mathrm{~s}^{-1}$. One of the mechanisms for strengthening nanostructured bainitic steel is the deformation-induced transformation of retained austenite into martensite. The occurrence of this transformation and the degree of its occurrence depends on the value of deformation and strain rate and the uniformity of deformation in the sample's volume. Fig. 3 presents examples of compression curves for samples with a diameter of $5.0 \mathrm{~mm}$ for strain rates of 550 and $870 \mathrm{~s}^{-1}$.

After repeated dynamic deformation, the samples were subjected to macro- and microstructure examination and the hardness distribution was determined on the cross-section parallel to the compression direction. Adiabatic shear bands were found where hardness exceeded $700 \mathrm{HV}$. In the deformed samples the hardness of the matrix (outside of the zones with the highest hardness) increased to the range of 660-680 HV (Fig. 4).

Fig. 5a shows the curves of double dynamic compression $\left(50 \mathrm{~s}^{-1}\right)$ using the Gleeble simulator with the first deformation of 0.12 and the second 0.33. The shape of the curves in the range of strain hardening in the second stage of compression in relation to the material compressed once did not change significantly, except for a slight increase in stress level. The double compression curves assumed a significantly different character, for which the deformation in the first stage was 0.25 and 0.35 , and in the next one 0.25 and 0.15 , respectively (Fig. 5b). The material during the first compression was strengthened as a result of a partial transformation of austenite into martensite and an increase in dislocation density. Retained austenite is enriched in carbon in relation to the bainitic matrix and average carbon content in steel. Prior to the second deformation, the microstructure of the steel was composed of lower carbide-free bainite laths (nanobainite), retained austenite, and high-carbon martensite formed from a portion of retained austenite ("fresh martensite"). The material in such a structural state does not have the ability to strain hardening, and during compression there is a decrease in stress with an increase in strain due to local temperature increase and consequently, changes in the microstructure. 


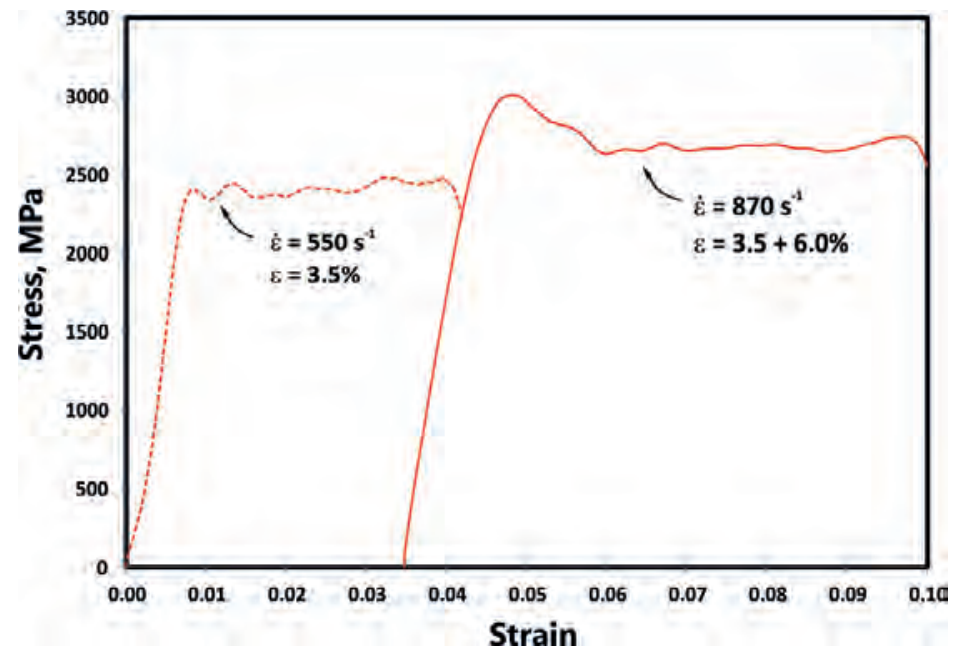

Fig. 3. Dynamic stress-strain curves obtained as a result of double compression under the Hopkinson test conditions Rys. 3. Krzywe naprężenie-odkształcenie dynamiczne uzyskane w wyniku dwukrotnego ściskania w warunkach testu Hopkinsona
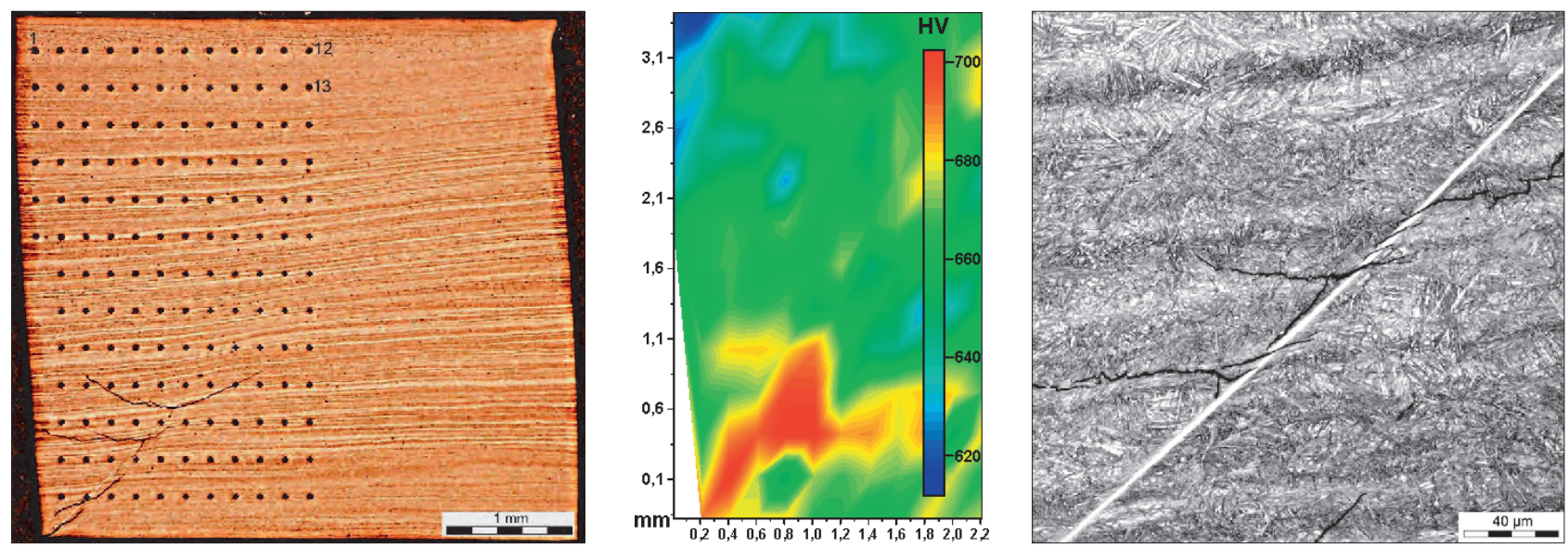

Fig. 4. Macrostructure, microstructure and hardness distribution after a double dynamic deformation. Sample with a diameter of 4.0 mm; deformation $(\%) /$ strain rate $\left(\mathrm{s}^{-1}\right): \mathbf{1 1 . 5} / \mathbf{1 9 0 0 + 4 . 3 / 1 1 6 0}$

Rys. 4. Makrostruktura, mikrostruktura i rozkład twardości po dwukrotnym odkształceniu dynamicznym. Próbka o średnicy 4,o mm; odkształcenie $(\%) /$ prędkość odkształcenia $\left(\mathrm{s}^{-1}\right): 11,5 / 1900+4,3 / 1160$

a)

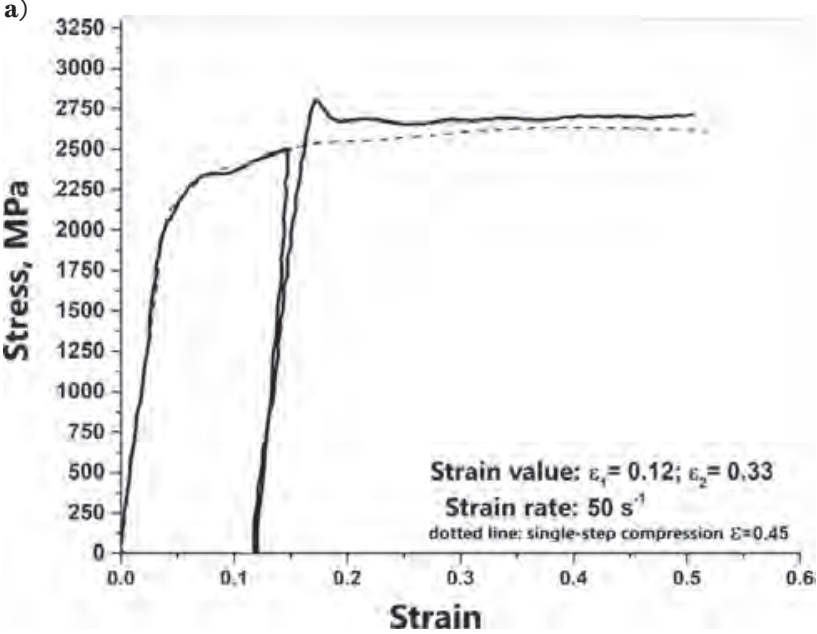

b)

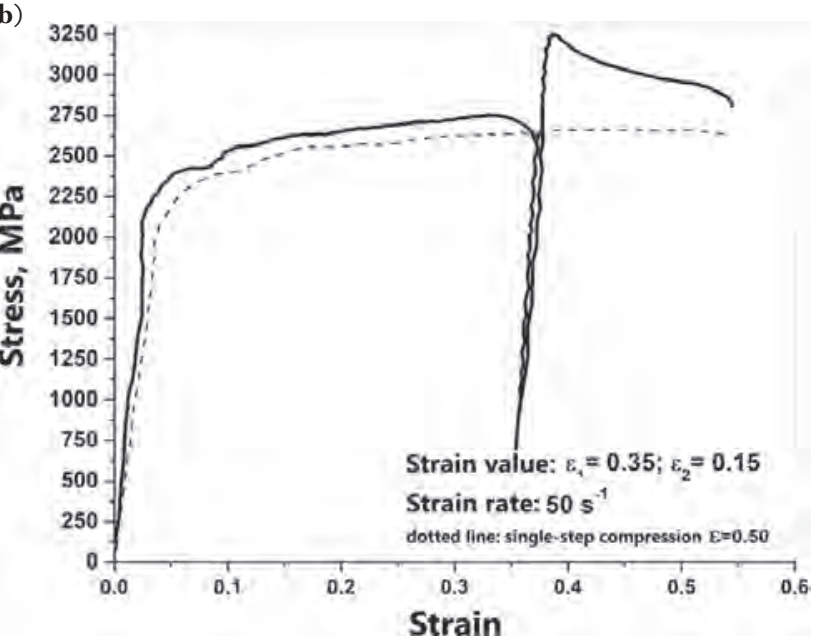

Fig. 5. Dynamic stress-strain curves obtained as a result of double compression using a Gleeble simulator. Sample with a diameter of $5.0 \mathrm{~mm}$

Rys. 5. Krzywe naprężenie-odkształcenie dynamiczne uzyskane w wyniku dwukrotnego ściskania za pomocą symulatora Gleeble. Próbka o średnicy 5,0 mm 
After repeated dynamic deformation with the Gleeble simulator, the samples were subjected to macro- and microstructure examination and the hardness distribution was determined on the cross-section parallel to the compression direction. The macrostructure and microstructure examination, as well as the hardness distribution of a sample compressed up to a deformation value of 0.60 showed the presence of adiabatic shear bands in which cracks occurred. The results of the examination of the macro- and microstructure and hardness distribution measurement of samples after double uniaxial compression are presented in Fig. 6. Zones where hardness reached $800 \mathrm{HV}$ were observed. No adiabatic shear bands were found in the material after double compression tests.
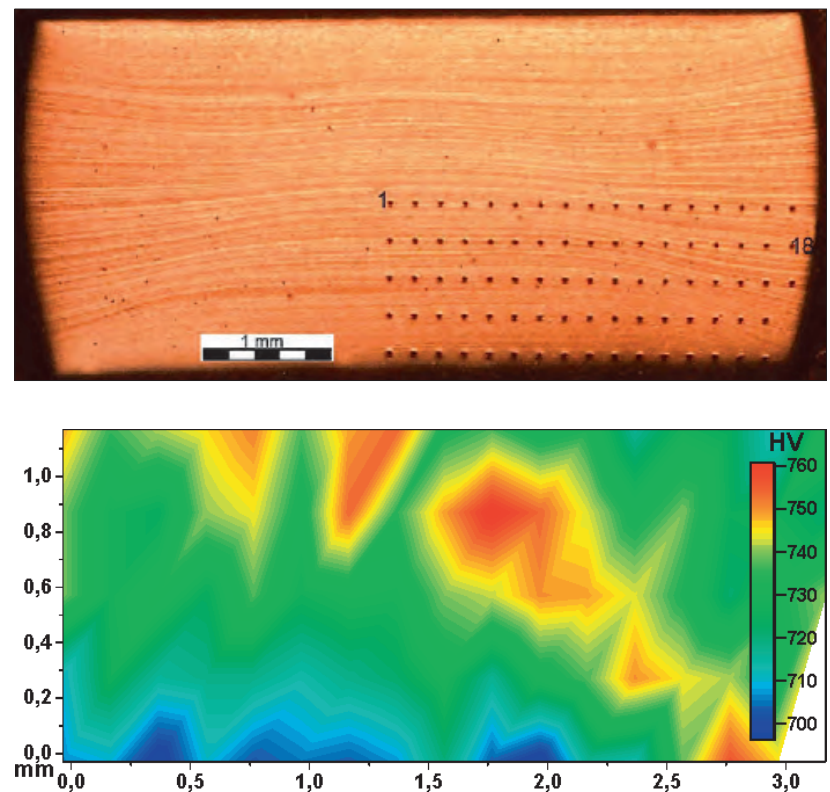

Fig. 6. Macrostructure and hardness distribution after double dy namic deformation with a strain rate of $50 \mathrm{~s}^{-1}$. Sample with a diameter of $5.0 \mathrm{~mm}$, strain: $0.25+0.25$

Rys. 6. Makrostruktura oraz rozkład twardości po dwukrotnym odkształceniu dynamicznym z prędkością odkształcenia $50 \mathrm{~s}^{-1}$. Próbka o średnicy 5,0 mm; odkształcenie: 0,25+0,25

\section{FIRING TESTS RESULTS}

The firing tests of $8.5 \mathrm{~mm}$ thick sheets from industrial heat with chemical composition $0.58 \% \mathrm{C}-1.95 \% \mathrm{Mn}-1.8 \% \mathrm{Si}-$ $1.30 \% \mathrm{Cr}-0.67 \% \mathrm{Mo}$ (weight \%) were carried out at Military Institute WITPiS. The material was subjected to firing tests after a two-stage heat treatment, i.e. isothermal annealing was carried out at two temperatures. The detailed test results for the material after the two-stage heat treatment are contained in research report [8]. The reference variant were sheets subjected to a single-stage treatment at isothermal transformation temperature of $210^{\circ} \mathrm{C}$ for 120 hours. Variant $210 / 120$ had a UTS higher than $2100 \mathrm{MPa}$ and YS of approx. $1300 \mathrm{MPa}$, with an TE of $11-14 \%$. Sheets after the two-stage treatment were characterised by UTS in the range of 1999$2089 \mathrm{MPa}$, YS of $1250-1450 \mathrm{MPa}$ and TE of $11.5-14.7 \%$. The tested variants were varied in terms of volume fraction of retained austenite: from $16 \%$ - reference variant, to $33 \%$.

Multi-hit firing tests were carried out using two types of ammunition: cal. 5.56×45 mm M193 (Stanag 4569 level 1) and cal. 7.62×39 mm API BZ (Stanag 4569 level 2). Positive test result - meeting the above-mentioned protection level means no complete perforation of the sheet under multi-hit firing test conditions in the following rate range: M193: $937 \pm 20 \mathrm{~m} / \mathrm{s}(917-957 \mathrm{~m} / \mathrm{s}) ; \mathrm{BZ}: 695 \pm 20 \mathrm{~m} / \mathrm{s}(675-715 \mathrm{~m} / \mathrm{s})$.

Tables 3 and 4 present examples of firing test results for $8.5 \mathrm{~mm}$ thick sheets in the $210 / 120$ reference variant and the $210 / 60+275 / 30$ two-stage variant. The sheet in the reference variant showed resistance to perforation and cracking under conditions of multi-hit firing with M193 and BZ ammunition. The firing tests using the BZ ammunition were conducted in the upper limit velocity range specified in Stanag 4569-level 2, and even outside this range. Test No. 7 - ammunition M193 was not qualified due to the velocity outside the range of requirements specified in Stanag 4569 . The sheet in the two-stage variant did not pass the firing tests for both types of ammunition for the highest maximum projectile velocities.

Fig. $7 \mathrm{a}$ and $8 \mathrm{a}$ show the results of macrostructure examination at the M193 projectile impact site. Typical effects of dynamic impact were found, such as the formation of cracks at a certain distance with the axis of impact of the core and adiabatic shear bands near the sheet surface. In assessing

Table 3. Results of firing tests and a photograph of the sheet after the tests. Variant 210/120

Tabela 3. Wyniki testów ostrzałem oraz fotografia blachy po testach. Wariant 210/120

\begin{tabular}{|c|c|c|c|c|c|}
\hline $\begin{array}{c}\text { Sample } \\
\text { identification }\end{array}$ & Ammunition & $\begin{array}{c}\text { Shot } \\
\text { number }\end{array}$ & $\begin{array}{c}\text { Projectile } \\
\text { velocity } V U \\
{[\mathrm{~m} / \mathrm{s}]}\end{array}$ & Photograph of the sheet after firing & Result \\
\hline \multirow{7}{*}{$\begin{array}{c}\mathrm{NBA}-210 / 120, \\
\quad \# 8.5 \mathrm{~mm}\end{array}$} & \multirow{4}{*}{$\begin{array}{c}7.62 \times 39 \mathrm{~mm} \\
\text { API BZ }\end{array}$} & 1 & 715.6 & & No perforation \\
\hline & & 2 & 712.3 & & No perforation \\
\hline & & 3 & 714.3 & 76 & No perforation \\
\hline & & 4 & 731.2 & 1 & No perforation \\
\hline & \multirow{3}{*}{$\begin{array}{c}5.56 \times 45 \mathrm{~mm} \\
\mathrm{M} 193\end{array}$} & 5 & 954.5 & 3 & No perforation \\
\hline & & 6 & 942.2 & 2 & No perforation \\
\hline & & 7 & 976.5 & & Perforation \\
\hline
\end{tabular}


Journal of Metallic Materials 2019, 71 (2), p. 14-22

Table 4. Results of firing tests and a photograph of the sheet after the tests. Variant 210/60+275/30

Tabela 4. Wyniki testów ostrzałem oraz fotografia blachy po testach. Wariant 210/60+275/30

\begin{tabular}{|c|c|c|c|c|c|}
\hline $\begin{array}{c}\text { Sample } \\
\text { identification }\end{array}$ & Ammunition & $\begin{array}{c}\text { Shot } \\
\text { number }\end{array}$ & $\begin{array}{c}\text { Projectile } \\
\text { velocity } V U \\
{[\mathrm{~m} / \mathrm{s}]}\end{array}$ & Photograph of the sheet after firing & Result \\
\hline \multirow{8}{*}{$\begin{array}{c}210 / 60+273 / 30, \\
\# 8.5 \mathrm{~mm}\end{array}$} & \multirow{4}{*}{$\begin{array}{c}5.56 \times 45 \mathrm{~mm} \\
\mathrm{M} 193\end{array}$} & 1 & 944.5 & & No perforation \\
\hline & & 2 & 951.9 & & Perforation \\
\hline & & 3 & 956.6 & & No perforation \\
\hline & & 4 & 952.2 & & No perforation \\
\hline & \multirow{4}{*}{$\begin{array}{c}7.62 \times 39 \mathrm{~mm} \\
\text { API BZ }\end{array}$} & 5 & 717.8 & & No perforation \\
\hline & & 6 & 716.5 & & No perforation \\
\hline & & 7 & 709.3 & & No perforation \\
\hline & & 8 & 716.2 & & Perforation \\
\hline
\end{tabular}

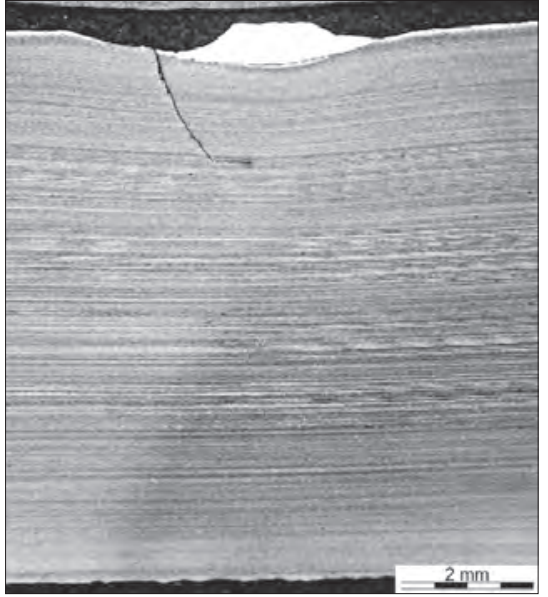

b)

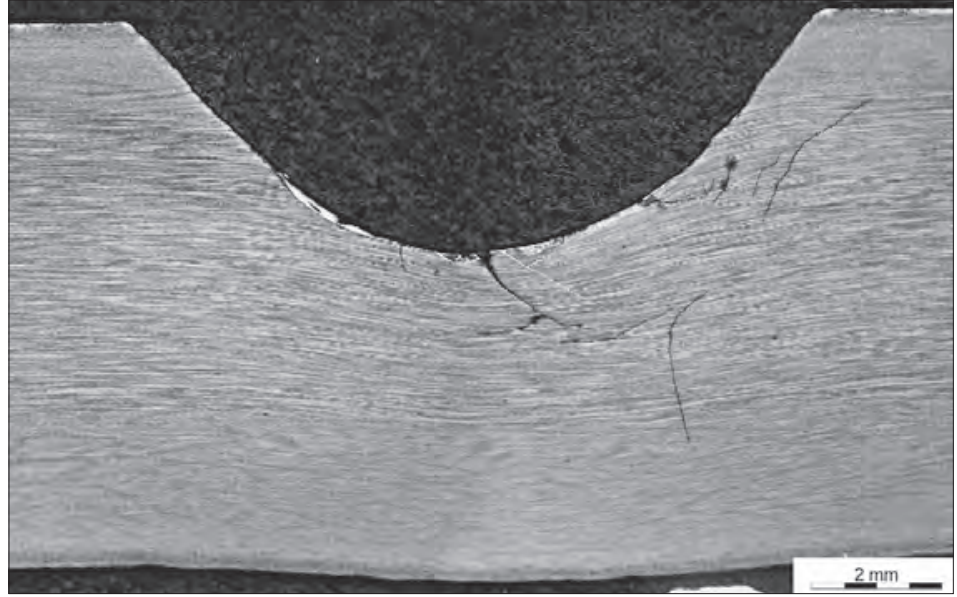

Fig. 7. Macrostructure in the area of the impact of projectile M193 (a) and BZ (b). Variant 210/120

Rys. 7. Makrostruktura i mikrostruktura w obszarze uderzenia pocisku M193 (a) i BZ (b). Wariant 210/120

a)

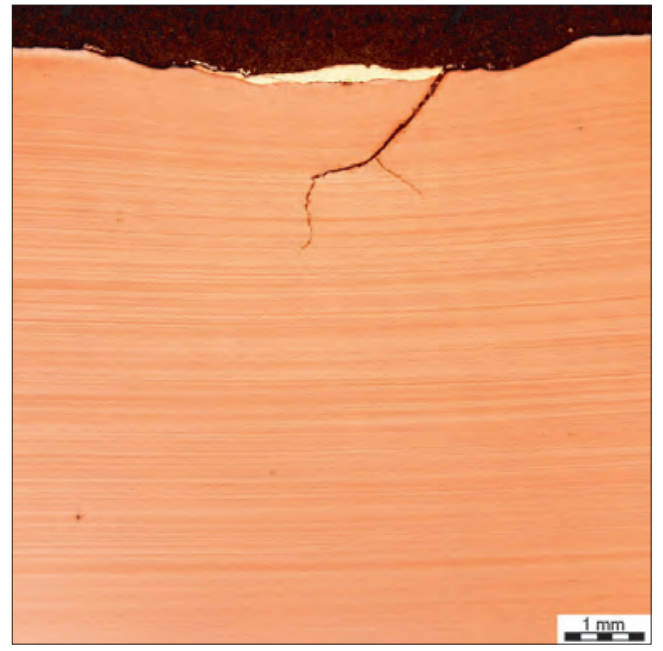

b)

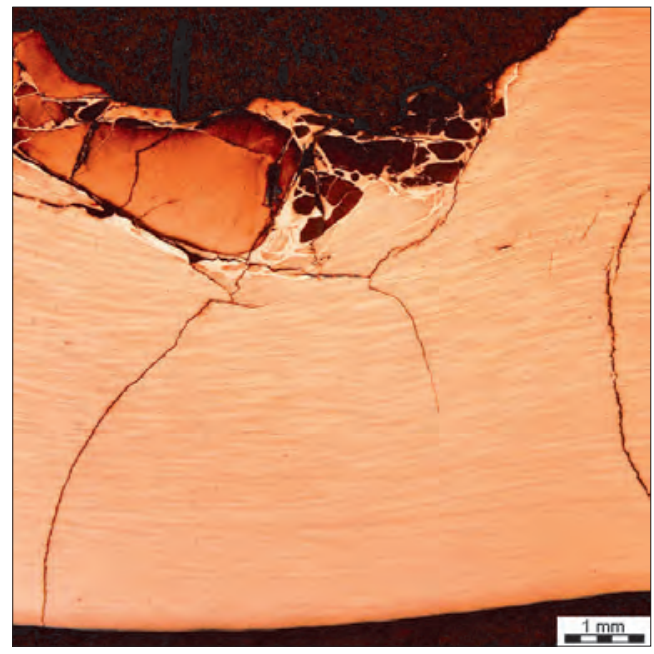

Fig. 8. Macrostructure in the area of the impact of projectile M193 (a) and BZ (b). Variant 210/60+275/30

Rys. 8. Makrostruktura i mikrostruktura w obszarze uderzenia pocisku M193 (a) i BZ (b). Wariant 210/60+275/30 
the effects of degradation, the extent of cracking (length) in relation to the thickness of the sheet is important. In the analysed case, the crack length reached about $1 / 4$ of the sheet thickness, which is a positive result in terms of resistance during subsequent impacts. A favourable phenomenon of crack inhibition was observed, in particular a change of direction from parallel to perpendicular to the normal to the sheet surface. Fig. $7 \mathrm{~b}$ and $8 \mathrm{~b}$ show the results of macrostructure examination at the $\mathrm{BZ}$ projectile impact sites. The perforation range in the examined areas, measured by the depth of penetration of the core, was in the range of 3-4 $\mathrm{mm}$. Different perforation is clearly visible in the generation of cracks, of which the most dangerous are parallel to the normal to the sheet surface. It is not possible to control and register all test parameters during firing and they may differ despite similar velocity. The differences are related to, among others, core mass deviations, which affect the value of kinetic energy, the shape of the core and the axiality of the impact on the sheet (depending on the stabilisation of the projectile's flight path). An additional variable are dimensional deviations of sheet thickness of up to $0.3 \mathrm{~mm}$. These parameters may be important in the case of investigation of sheets with critical thickness for specific firing test conditions (type of ammunition and range of projectile velocity).

\section{SUMMARY}

The paper presents the results of testing the mechanical properties and microstructure of nanostructured bainitic steel in order to determine the range of isothermal annealing parameters, enabling obtaining high resistance to perforation. Based on previous studies, it was assumed that a UTS above $2000 \mathrm{MPa}$ and a YS higher than approx. 1250 $\mathrm{MPa}$ are required to pass the firing tests. The listed values were met for several heat treatment variants with an annealing temperature of 210 and $225^{\circ} \mathrm{C}$ and times of 96 and 120 hours and 72 and 96 hours respectively. In addition, variants after a two-stage isothermal treatment were tested. Analyses, measurement and studies on the morphology of retained austenite were performed, as its volume fraction may have a significant impact on the ability to absorb and dissipate impact energy. Variants 210/120 and 225/72 with a favourable set of mechanical properties and high perforation resistance (found in firing tests performed in other studies) were characterised by a retained austenite content of approximately 16 and $27 \%$, respectively, in which the blocky austenite content was $13 \%$ in both cases.

The analysis of examination results of nanostructured bainitic steel subjected to multiple uniaxial compression under dynamic deformation was presented. The experiment was carried out at a wide range of strain rate: $300-1900 \mathrm{~s}^{-1}$ with Hopkinson bar and $50 \mathrm{~s}^{-1}$ in a Gleeble simulator. Critical strain values were determined for the given ranges of deformation, after which the material significantly changes properties, in particular the ability to strain hardening and ductility. An analysis of structural changes occurring in the material as a result of dynamic deformation was carried out, taking into account the impact of localisation of deformation in the compression process. In the next compression, nanostructured bainitic steel initially deformed dynamically to the value of $5.3 \%$ at a deformation rate of $910 \mathrm{~s}^{-1}$ shows a constant level of stress with increased strain, i.e. it loses its ability to hardening. The application of the first deformation of $8.5 \%$ with a strain rate of $1070 \mathrm{~s}^{-1}$ causes significant changes in the mechanical properties of the material. At that time, nanostructured steel is characterised by a microstructure composed of carbide-free lathy bainite, retained austenite with high carbon content due to the diffusion of this element during long-term isothermal transformation, and high-carbon martensite formed from retained austenite as a result of deformation-induced transformation. This type of material shows a clear decrease in stress during the subsequent deformation. For a strain rate of $50 \mathrm{~s}^{-1}$, the first deformation of 0.12 (approx. 10\%) causes such material changes in properties that during repeated compression to 0.33 (approx. $25 \%$ ), the material deforms under constant stress. In turn, the first deformation of 0.25 (approx. 20\%) results in a significant change in mechanical properties. In the next stage of dynamic compression, the steel shows a decrease in stress with an increase in strain. As a result of double dynamic deformation under the Hopkinson test conditions, a local increase in hardness was obtained from the initial value of $610 \mathrm{HV}$ to $700 \mathrm{HV}$. When compressed using the Gleeble simulator, the hardness increased locally to $800 \mathrm{HV}$. The hardness of martensite in the tested steel with a carbon content of approx. $0.60 \%$ on the basis of dilatometric study is approx. $770 \mathrm{HV}$. The hardness of the non-deformed bainitic-austenitic matrix is approx. $610 \mathrm{HV}$. Therefore, the increase in hardness results from the presence of high-carbon martensite formed as a result of the deformation-induced transformation from retained austenite and from the increase in dislocation density in lathy bainite and in the remaining retained austenite. In the process of dynamic deformation of nanostructured steel, opposing phenomena occur: deformation transformation of high-carbon retained austenite into martensite and an increase in dislocation density - causing an increase in stress and local phenomena of concentration of deformation, which is the cause of temperature increase - causing a decrease in stress ("thermal weakening effect"). The magnitude of the impact of individual phenomena determines the overall effect of strengthening the material. These phenomena cause changes in the microstructure, which result, among others, in changes in material ductility and energy absorption capacity. In addition, the tendency to transformation of retained austenite or the increase in dislocation density are strongly dependent on the strain rate and method of deformation, and the material's susceptibility to localisation of deformation. In nanostructured bainitic steel, retained austenite occurs in the form of thin layers between bainite laths and in the form of separate grains. The mechanical and thermodynamic stability of austenite significantly depends on its carbon content as well as on the size, morphology and location relative to the other components of the microstructure. The assessment of the impact of retained austenite on the behaviour of nanostructured bainitic steels in the process of dynamic deformation, including multiple deformation, requires further advanced material research in the field of determining the volume fraction of individual morphological types of this phase and determining the carbon content in them.

Based on the results of firing tests and structure examination in places of projectile impact, a set of mechanical properties values (determined in a static tensile test) were proposed, which guarantee the protective capabilities. An important issue was to indicate the optimal variant to meet the level of protection against the impact of two types of projectiles that are the subject of this paper: M193 (cal. $5.56 \times 45 \mathrm{~mm}$ ) and BZ (cal. $7.62 \times 39 \mathrm{~mm})$. Variant $210 / 120$ with a minimum UTS of $2100 \mathrm{MPa}$, YS of approx. $1300 \mathrm{MPa}$ and TE of $11-14 \%$ met the requirements of resistance to perforation with the M193 and BZ projectiles in accordance 
with the requirements of the Stanag 4569 document for levels 1 and 2. None of the tested two-stage treatment variants, characterised by lower UTS, met the perforation resistance requirements for both of the above types of projectiles. The closest to pass firing tests using both types of ammunition was the $210^{\circ} \mathrm{C} / 60 \mathrm{~h}+275^{\circ} \mathrm{C} / 30 \mathrm{~h}$ variant with an UTS of $2020 \mathrm{MPa}$ and a volume fraction of retained austenite of $19-24 \%$. Other variants met the requirements of the M193 firing test, but did not meet the requirements for firing with the $\mathrm{BZ}$ ammunition. The comparative tests show that the key material parameter in the case of nanobainitic steel is ultimate tensile strength and retained austenite content. The optimal volume fraction of retained austenite was found to be between 15 and $20 \%$. The yield strength value in the tested range of 1250-1450 MPa and total elongation from 11 to $15 \%$ had no effect on perforation resistance. The indicated range of elongation is sufficient to guarantee the sheets' resistance to cracking under multiple firing conditions.

\section{CONCLUSION}

Based on the analysis of firing test results as well as the examination of microstructure and mechanical properties of nanostructured bainitic steel, it was shown that in order to meet the requirements of level 2 ballistic protection according to Stanag 4569, a sheet made of tested steel with a minimum thickness of $8 \mathrm{~mm}$, with a minimum UTS of min. $2100 \mathrm{MPa}$, TE above $11 \%$ and a volume fraction of retained austenite in the range of $15-20 \%$ should be used.

\section{REFERENCES}

[1] Final report - Research Fund for Coal and Steel - European Commission, RFSR-CT-2012-00017. Understanding basic mechanism to optimize and predict in service properties of nanobainitic steels (MECBAIN), EUR 28463 EN, 2017.

[2] Y.T. Tsai, Y.W. Chen, J.R. Yang. Severe deformation of nanostructured bainitic steel. Procedia Engineering, 2017, 207, p. 1862-1867.

[3] L. Morales-Rivas, C. Garcia-Mateo, T. Sourmail, M. Kuntz, R. Rementeria, F.G. Caballero. Ductility of Nanostructured Bainite. Metals, 2016, 6 (12), p. 302. doi:10.3390/met6120302.

[4] T. Sourmail, C. Garcia-Mateo, F. G. Caballero, L. Morales-Rivas, R. Rementeria, M. Kuntz. Tensile Ductility of Nanostructured Bainitic Steels: Influence of Retained Austenite Stability. Metals, 2017, 7 (1), p. 31. doi:10.3390/met7010031.

[5] L. Morales-Rivas. Microstructure and mechanical response of nanostructured bainitic steels. PhD Thesis. National Center for Metallurgical Research (CENIM-CSIC), Spain, 2016.
[6] L. Morales-Rivas, C. Garcia-Mateo, M. Kuntz, T. Sourmail, F.G. Caballero. Induced martensitic transformation during tensile test in nanostructured bainitic steels. Mater. Sci. Eng. A, 2016, 662, p. $169-177$.

[7] F. Hu, K.M. Wu, P.D. Hodgson. Effect of retained austenite on wear resistance of nanostructured dual phase steels. Mater. Sci. Tech., 2016, 32 (1), p. 40-48.

[8] J. Marcisz, B. Walnik, J. Gazdowicz. Dostosowanie technologicznych i aplikacyjnych właściwości wysokowytrzymałych stali do wzrastajacych wymagań przemystu obronnego. IMŻ Report No. So-0950, 2017. [unpublished].

[9] B. Garbarz, W. Zalecki, B. Walnik, A. Wrożyna, P. Skupień. Opracowanie metody regulowania sktadu fazowego ultrawytrzymatych stali nanostrukturalnych w celu uzyskania wytrzymatości $i$ ciagliwości dostosowanych do różnych warunków eksploatacji, IMŻ Report No. So-0925, 2016. [unpublished]. 